${ }^{\circledR}$ Entomologica Fennica. 27 September 1999

\title{
Additions to the revisions of the genus Stilpnus (Hymenoptera, Ichneumonidae) of the Palaearctic Region. I.
}

\author{
Reijo Jussila
}

Jussila, R. 1999: Additions to the revisions of the genus Stilpnus (Hymenoptera, Ichneumonidae) of the Palaearctic Region. I. - Entomol. Fennica 10: 107-112.

New and additional information on Palaearctic species of the genus Stilpnus is given. The males of Stilpnus bottnicus Jussila and S. fallax Foerster are described. $S$. fallax is also new to the Finnish fauna. A revised key to the males is presented.

Reijo Jussila, Krouvintie 92, FIN-21330 Paattinen, Finland; e-mail: reijo. jussila@utu.fi

Received 25 February, accepted 22 April 1999

This paper is the first addition to my revisions of the genus Stilpnus Gravenhorst, 1829 of Europe, Japan and Taiwan (Jussila 1987 and 1988). After those two papers I have had a possibility to study a great number of Stilpnus specimens from different places in the Palaearctic Region. Therefore, I am able to go more closely into the taxonomy and faunistics of this genus.

The morphological terminology adopted in this work follows that used by Gauld \& Bolton (1988) and Gauld (1991).

\section{Subgenus Polyrhembia Foerster, 1868}

Stilpnus tenebricosus (Gravenhorst, 1829)

This species has been found in the whole of Finland and almost the entire Europe. New countries are the Netherlands ( 19 in Itterem 29.IX.1962, van Oostsroom leg.) and Ukraine ( 10 and 2 o 9 in the Carpathians VII.-VIII.1989, D. Kasparyan leg.). In Russia it has been found in the Murmansk region (2 $\sigma^{\star} \sigma^{\star}$ and 3 o $o$ 30.VII.-1.VIII.1974), the Polar Ural: Vorkuta (1 $\&$ 11.VII.1972), and Siberia: Yakutia (4o $\sigma^{\star}$ and $2 \%$ \% 16.-31.VII.1990) and
Kamchatka (2우 ㅇ 16.-17.VII.1985), Kasparyan leg.

Subgenus Xestophyes Foerster, 1868

Stilpnus dryadum Curtis, 1832

This species has been found only in Finland (two o ㅇ from $A$ : Lemland and $T a$ : Lempäälä) and the British Isles. A new place of discovery in Finland is $A b$ : Houtskari, Hyppeis 669:18 1-30.VI.1990 (one $\sigma^{*}, \mathrm{H}$. Bruun leg.).

Stilpnus fallax (Foerster, 1876)

The only specimen known hitherto has been the holotype female from Germany. Three male specimens have now been established from Finland, $A l$ : Lemland, $S b$ : Nilsiä and $L i$ : Lemmenjoki (W. Hellén leg.), and altogether 4 ㅇ $q$ from Finland, Al: Jomala (Hellén leg.), and Russia: St. Petersburg (11.VIII.1972), Western Siberia: Taz (12.VIII.1992) and Yakutia: the delta of Lena (23.VII.1990 in Tit-Ary, $80 \mathrm{~km} \mathrm{NW}$ of Tiksi) (Kasparyan leg.). The species is new to the Finn- 
ish and Russian fauna. The male sex has hitherto been unknown.

Male. Length 3.0-3.5 mm. Head polished, face obscurely and shallowly punctured; vertex rounded but not narrowed behind compound eyes; temple uniformly broad; genal carina straight; occipital carina rounded in its middle part; malar space $0.8-0.85 \mathrm{x}$ width of mandible; clypeus fairly convex, polished with obscure and shallow punctures, width about $2.0 \mathrm{x}$ length; upper tooth of mandible slightly longer and wider than lower tooth; compound eye bare; flagellum with 18 segments, length-to-thickness ratios: $1^{\text {st }}$ segment about 3.5 , $2^{\text {nd }} 2,4,10^{\text {th }}$ and penultimate about 1.2. Mesoscutum polished, with some punctures on its lateral part, notaulus reaching about 0.5 the distance to scutellum; mesopleuron polished, propodeum sparsely chagrined, bearing distinct carinae, median area \pm parallel-sided, its length about $2.5 \mathrm{x}$
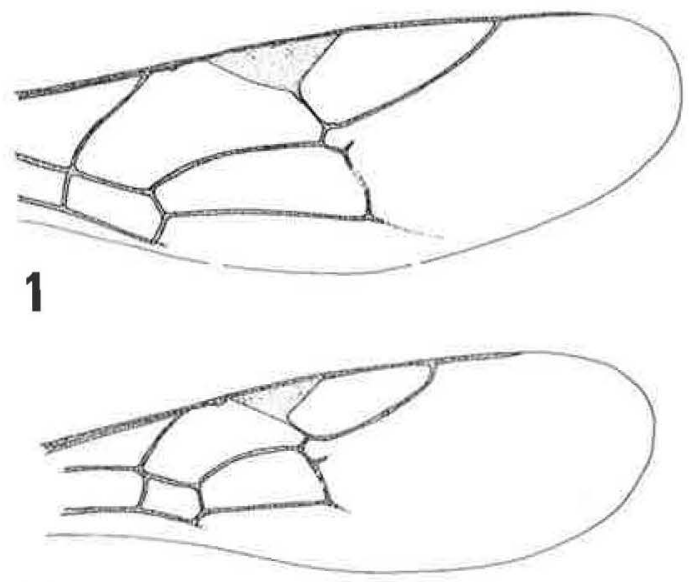

2

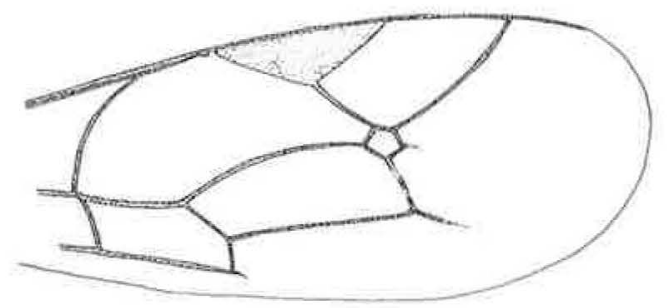

3

Figs. 1-3. Fore wing of the male. - 1. Stilpnus fallax (Foerster). - 2. S. montanus (Foerster). - 3. S. bottnicus Jussila. its width, no apophysis or crest. Areolet in front wing open, $2 \mathrm{~m}$-cu generally with one bulla, sloping outward posteriorly so that posterodistal corner of $2^{\text {nd }}$ discoidal cell is about $60^{\circ}$, length of $2^{\text {nd }}$ discoidal cell 2.9-3.4 x its breadth (Fig. 1); abscissa of $\mathrm{Cu}$ between $\mathrm{M}+\mathrm{Cu}$ and $\mathrm{cu}-\mathrm{a}$ as long as cu-a in hind wing. Length of hind femur about $5.7 \mathrm{x}$ its width; tarsal claws not longer than arolium. Metasoma, seen from above, fairly broad, its length (without $1^{\text {st }}$ segment) $2.0-3.0 \mathrm{x}$ its width; apex of segment 1 , seen from side, rather curved, cross section of petiole somewhat depressed, postpetiole 1.1-1.2 $\mathrm{x}$ as long as wide; tergite $1 \mathrm{rugu}$ lose but without punctures, longitudinal carinae weak.

Black; brownish to brownish yellow on mandibles, apical ridge of clypeus and tegulae. Metasoma dorsally black, dark brown on middle part. Legs brownish yellow; brown on coxae and femora.

'I'he male resembles the female but in the latter the vertex is rounded and moderately narrowed behind the compound eyes, the oral part of the temple is broadest, the flagellum has 15 segments and is somewhat thickened towards the apex, and the median area of the propodeum is broadest in its middle. The $S$. fallax male also resembles the male of $S$. montanus but it is bigger (length of montanus $2.0-2.1 \mathrm{~mm}$ ) and more robust, its flagellum thicker (length-to-thickness ratios in montanus are 4.6-4.7, 2.8-2.9 and 1.2-1.3) and the venation a little different (see the key and and the Figs. 1 and 2).

\section{Stilpnus montanus (Foerster, 1876)}

This species has been found only in Finland ( $E H$ : Ruovesi), Germany, Switzerland and Russia (Murmansk, Trifona). New finds in Russia have been made in Yakutia: the delta of the Lena river (3 $\sigma^{\top} \sigma^{\top}$ and 5 우 from Tit-Ary and Tiksi 22.VII.2.VIII.1990, Kasparyan leg.).

\section{Stilpnus oligomerus (Foerster, 1876)}

Earlier this species has been found in Southern and Central Finland, Poland and Germany. A new country is Russia (one 9 near St. Petersburg 2.VII. 1972, Kasparyan leg.). 


\section{Subgenus Stilpnus Gravenhorst, 1829}

Stilpnus adanaensis Kolarov \& Beyarslan, 1994

The only known specimen of this species, the holotype male, has been found in Turkey, Adana 20.III.1985 (A. Beyarslan leg.).

For more details of the place of discovery and the description with the figures of the holotype, see Kolarov \& Beyarslan 1994.

\section{Stilpnus blandus Gravenhorst, 1829}

The species has been found in the whole of Finland and in the greater part of Europe. A new country is Scotland (altogether $7 \sigma^{\star} \sigma^{\star}$ and 12 우, M. R. Shaw \& al. leg.).

\section{Stilpnus bottnicus Jussila, 1987}

This species has been found only in Southern and Central Finland (females from $\mathrm{Al}$ to $\mathrm{Om}$ ). $2 \sigma^{*} \mathrm{o}^{*}$ and 3 ㅇ $q$ have also been collected in $A b$ : Turku, Ruissalo 671:23 22.VII.-17.VIII. 1988, R. Jussila leg.). The male sex has been hitherto unknown.

Male. Length 3.0-3.5 mm. Head polished, malar space chagrined, face obscurely and shallowly punctured; vertex not or somewhat narrowed behind compound eyes; temple uniformly broad; genal carina straight; occipital carina rounded in middle part; malar space about $1.0 \mathrm{x}$ width of mandible; clypeus not convex, median 0.2 of ventral ridge slightly blunt, polished with some shallow punctures, width about $2.0 \mathrm{x}$ length; upper tooth of mandible slightly longer and wider than lower tooth; compound eye bare; lengthto-thickness ratios of flagellar segments: $1^{\text {st }}$ segment about $4.0,2^{\text {nd }} 3.2,3^{\text {rd }} 2.8$, and $10^{\text {th }}$ about 2.0 . Mesoscutum polished, notaulus reaching about 0.3 the distance to scutellum; mesopleuron polished; propodeum polished, sparsely chagrined, bearing distinct carinae, median area parallel-sided, somewhat chagrined, its length about $2.0 \mathrm{x}$ its width, no apophysis or crest. Areolet of front wing closed, $2 \mathrm{~m}$-cu with two bullae, sloping outward posteriorly so that posterodistal corner of $2^{\text {nd }}$ discoidal cell is about $70^{\circ}$, length of $2^{\text {nd }}$ discoidal cell about $2.7 \mathrm{x}$ its breadth (Fig. 3); abscissa of
$\mathrm{Cu}$ between $\mathrm{M}+\mathrm{Cu}$ and cu-a distinctly longer than cu-a in hind wing. Length of hind femur about $4.7 \mathrm{x}$ its width; tarsal claws not longer than aro lium. Gaster, seen from above, not so narrow, its length (without $1^{\text {st }}$ segment) 2.2-2.4 $\mathrm{x}$ its width; apex of segment 1 , seen from side, somewhat curved, cross section of petiole a little depressed, postpetiole 1.1-1.3 $\mathrm{x}$ as long as wide; tergite 1 chagrined and polished, longitudinal carinae weak, tergite 2 smooth and polished.

Black; yellowish to brownish yellow on tegulae, mandibles (except for dark brown teeth) and proximal parts of antennae. Metasoma dorsally black. Legs brownish yellow; hind coxae basally brown to brownish yellow.

The male resembles the female but in the latter the vertex is not narrowed behind the compound eyes, the length of the malar space about $1.2 \mathrm{x}$ width of the mandible, the flagellum somewhat thickened towards the apex. It also resembles the male of $S$. gagates but the latter is bigger (length about $4.3 \mathrm{~mm}$ ), the flagellae are distinctly thicker (ratios 3.8-3.9, 2.3-2.5, 1.4-1.5 and 1.0) and the median area of the propodeum is broader (ratio about 1.6) and the hind femora are thicker (ratio 4.9-5.2).

\section{Stilpnus crassicornis Thomson, 1884}

This species has earlier been found in Southern and Central Finland, Sweden, Ireland, England, Poland, Bulgaria and USA. New countries are Scotland (1 1983 in Chippenham, Fen Cambs, M. Shaw leg.) and Russia (1 9 22.VII and $10^{*}$ 3.VIII. 1975 in Transbaikalia, Chita region and 2 우 우 in"Smolensk poozer'e" National Park 22.VII. 1975, Kasparyan leg.).

\section{Stilpnus gagates (Gravenhorst, 1829)}

It has been found in Southern and Central Finland and nearly the whole of Europe. New countries are the Netherlands ( 1 \% in Ede 17.X.1965, van Rossem leg.), Scotland (altogether $15 \sigma^{\circ} \sigma^{\star}$ and 21 ㅇ ㅇ in many places 1951-1983) and Spain, Valencia ( $1 \sigma^{\top}$ from Alboraya and 1 f from Rio Turia, Alberti leg.). This species is rather common in Russia. 
Stilpnus parvulus Foerster, 1876

This species is rather common in Southern and Central Finland, and Northern and Central Europe. A new country is Russia (1 o 21.XI.1984 from St. Petersburg, Dibuny, V. Tobias leg.).

The length of the metasoma (without the $1^{\text {st }}$ segment) is 2,4-2.6 $\mathrm{x}$ its breadth, not about 1.4 as it is wrongly been written in Jussila 1987.

Stilpnus pavoniae (Scopoli, 1863)

This species is living in the whole of Finland and perhaps in the whole of Europe. It has also been found in Japan and Taiwan (Jussila 1988). New countries are Austria (1 $1{ }^{\top}$ from Oberösterreich 7.IX.1985 and 10 from Bamsteine near Hallein 10.X.1986, M. Schwarz leg.), the Netherlands (altogether $8 \sigma^{\star} \sigma^{\star}$ and 5 우 from Ede and Weckeromse Zand 1970-1983, van Rossem leg.) and Scotland (altogether $3 \sigma^{\circ} \sigma^{\circ}$ and $17 \% \circ$ in many places 1983-1988). In the European part of Russia altogether $5 \sigma^{*}$ and $27 \%$ o have been found from "Smolenskoe poozer'e" National Park, St. Petersburg, Novgorod and Jaroslavl regions 19751990. In Siberia this species has also been found: 1 f from Taz 12.VIII.1975, 3 우 from Jakutia, Jakutsk 8.-23.VII.1990, and $10^{\star}$ from Transbaikalia, Chita region 2.VIII.1975, Kasparyan leg. In Ukraine 2 o 9 have been found from the Carpathians (Tyachev and $12 \mathrm{~km}$ NNE of Bogdan 7.8.VII.1989, Kasparyan leg.

\section{Stilpnus rectangulus Roman, 1918}

This species has earlier been established in Southern and Central Finland, Sweden and Russia (the Kola peninsula), but now it has also been found in Finland from $L i$ : Utsjoki, Kevo 774:50 24.30.VII.1981 (1 \&, S. Koponen \& E. T. Linnaluoto leg.) and in Sweden from $V b$ : Kronlund, Hällnäs 11.IX.1976 (A. Nilsson leg.). In Russia this species has been found also in Yakutia: Lena ( 1 f from Zhigansk in the area between Yakutsk and Tiksi 16.-23.VII.1990, Kasparyan leg.) and Kamchatka (3우 from Kozyrevsk 16.-17.VII.1985, Kasparyan leg.).

\section{Stilpnus subzonulus Foerster, 1876}

This species has been distributed in Southern and Central Finland and nearly the whole of Europe. It has been found in Japan and Taiwan, too. New countries are the Netherlands $\left(20^{\circ} \sigma^{\circ}\right.$ and $2 \% q$ from Ede 21.IX.-9.X.1971, van Rossem leg.), Scotland $\left(8 \sigma^{\circ} \sigma^{*}\right.$ and $8 \% q$ in many places, Shaw leg.) and Spain ( $1 \sigma^{\star}$ from Valencia, Rio Turia, D. Alberti leg.).

\section{Renewed key to the males}

1. Flagellum with 16 segments; tyloids on segments 9-10. Metasoma very wide, its length (without $1^{\text {st }}$ segment) about $1.5 \mathrm{x}$ its breadth. Femora black (except for light apices of fore and middle femora). (To subgenus Stilpnus Gravenhorst)

adanaensis Kolarov \& Beyarslan

- Flagellum with 17 or more segments; tyloids at least on 3 segments. Metasoma narrower, its length at least $1.6 \mathrm{x}$ its breadth. At least apices of hind femora light ... 2

2. All femora (except for lighter apices) brown to black. Flagellum with 18-22 segments; distinct tyloids on segments 9-11 (in smaller specimens 7-9 or 8-10). Metasoma narrower, its length (without $1^{\text {st }}$ segment) more than $2.3 \mathrm{x}$ its width. (Subgenus Polyrhembia Foerster)

- Femora light. Flagellum with 17-19 segments; distinct tyloids on segments 7-9 (sometimes 8-10). Metasoma broader, its length less than $2.6 \mathrm{x}$ its width ................ 4

3. Flagellum with 19-22 segments; distinct tyloids on segments 9-11 (in smaller specimens 8-10). $2 \mathrm{~m}$-cu with two bullae. Metasoma (without $1^{\text {st }}$ segment) at most $3 \mathrm{x}$ as long as wide. Length 3.0-5.0 $\mathrm{mm}$

tenebricosus Gravenhorst

- Flagellum with 18 segments; distinct tyloids on segments 7-9. $2 \mathrm{~m}-\mathrm{cu}$ with one bulla. Metasoma about $3.3 \mathrm{x}$ as long as wide. Length $3.0-3.2 \mathrm{~mm}$. oligomerus (Foerster)

4. Areolet open (Figs. 1 and 2). (Subgenus Xestophyes Foerster) .. 5 
- Areolet closed (Fig. 3). (Subgenus Stilpnus Gravenhorst) 7

5. All flagellar segments very long and thin: length of $1^{\text {st }}$ segment about $6.0,2^{\text {nd }} 3.9$ and $10^{\text {th }} 1.5 \mathrm{x}$ its thickness ....... dryadum Curtis

- Flagellar segments shorter: length of $1^{\text {st }}$ segment 3.5-4.7, $2^{\text {nd }} 2.4-2.9$ and $10^{\text {th }} 1.3-1.4 \mathrm{x}$ its thickness.

6

6. Length $3.0-3.5 \mathrm{~mm}$. Malar space $0.8-0.85 \mathrm{x}$ width of mandible. Length of $1^{\text {st }}$ flagellar segment about $3.5 \mathrm{x}$ its thickness. $2 \mathrm{~m}$-cu generally with one bulla, sloping outward posteriorly so that posterodistal corner of $2^{\text {nd }}$ discoidal cell about $60^{\circ}$, length of $2^{\text {nd }}$ discoidal cell 2.9-3.4 $\mathrm{x}$ its breadth (Fig. 1)

fallax (Foerster)

- $\quad$ Length 2.0-2.1 mm. Malar space about $1.0 \mathrm{x}$ width of mandible. Length of $1^{\text {st }}$ flagellar segment about $4.0 \mathrm{x}$ its thickness. $2 \mathrm{~m}$-cu generally with two bullae, sloping outward posteriorly so that posterodistal corner of $2^{\text {nd }}$ discoidal cell about $70^{\circ}$, length of $2^{\text {nd }}$ discoidal cell 2.1-2.5 $\mathrm{x}$ its breadth (Fig. 2) montanus (Foerster)

7. Flagellar segments short and thick: thickness of $2^{\text {nd }}$ segment about 2.0 and $3^{\text {rd }}$ about $1.8 \mathrm{x}$ its length ................. crassicornis Thomson

- Flagellar segment longer and thinner ...... 8

8. $1^{\text {st }}$ flagellar segment very long and thin: its length at least $5.0 \mathrm{x}$ its thickness. Median area of propodeum broadest in its middle. $2 \mathrm{~m}$-cu bent and sloping outward posteriorly so that posterodistal corner of $2^{\text {nd }}$ discoidal cell is 60 $65^{\circ}$ (Fig. 18 in Jussila 1987)

subzonulus Foerster

$1^{\text {st }}$ flagellar segment shorter: its length at most $5.0 \mathrm{x}$ its thickness. $2 \mathrm{~m}$-cu not bent apically (Fig. 3) ... 9

9. $2 \mathrm{~m}$-cu sloping outward posteriorly, so that posterodistal corner of $2^{\text {nd }}$ discoidal cell is somewhat longer and more pointed (about $\left.60^{\circ}\right)$, length of $2^{\text {nd }}$ discoidal cell at least 2.8 $\mathrm{x}$ its breadth (Fig. 1 in Jussila 1987) ..... 10

- $2 \mathrm{~m}$-cu sloping outward posteriorly, so that posterodistal corner of $2^{\text {nd }}$ discoidal cell is somewhat shorter and less pointed $\left(70-75^{\circ}\right)$, length of $2^{\text {nd }}$ discoidal cell at most $2.7 \mathrm{x}$ its breadth (Fig. 3)
10. Malar space 1.0-1.2 $\mathrm{x}$ width of mandible. Flagellum with 19 segments; length-to-thickness ratios: $1^{\text {st }}$ segment $3.8-4.0,2^{\text {nd }}$ and $3^{\text {rd }}$ 2.0-2.2. Median area of propodeum most often broadest in its middle; lateral parts of apical transverse carina not strong or crestlike. Hind coxa basally brown to black or sometimes coxae wholly dark

blandus Gravenhorst

- Malar space about $0.7 \mathrm{x}$ width of mandible. Flagellum with 18 segments; length-to-thickness ratios: $1^{\text {st }}$ segment about $3.3,2^{\text {nd }} 1.8$ and $3^{\text {rd }} 1.5$. Median area of propodeum parallel-sided; lateral parts of apical transverse carina strong, crest-like (as in bottnicus and gagates). Legs wholly orange

rossicus Jussila

11. Vertex of head not narrowed behind compound eyes (Fig. 15 in Jussila 1987). Propodeum with strong carinae, lateral parts of apical transverse carina forming a crest 12

- Vertex narrowed behind compound eyes (Figs. 16 and 17 in Jussila 1987). Propodeum with \pm weak carinae ............................... 13

12. Length $3.0-3.5 \mathrm{~mm}$. Flagellum somewhat thinner: length-to-thickness ratios: $1^{\text {st }}$ segment about $4.0,2^{\text {nd }} 3.2,3^{\text {rd }} 2.8$, and $10^{\text {th }}$ about 2.0. Median area of propodeum narrower (ratio about 2.0) and hind femur thicker (ratio about 4.7) bottnicus Jussila

- Length about $4.3 \mathrm{~mm}$. Flagellum thicker: ratios 3.8-3.9, 2.3-2.5, 1.4-1.5 and 1.0. Median area broader (ratio about 1.6) and hind femur thinner (ratio 4.9-5.2)

\section{gagates Gravenhorst}

13. Median area of propodeum broadest in its middle. Occipital carina \pm angular in its middle part (Fig. 17 in Jussila 1987) parvulus Foerster

- Median area parallel-sided. Occipital carina rounded in its middle part (Fig. 16 in Jussila 1987). 14

14. Median area of propodeum \pm shining. $2 \mathrm{~m}$ $\mathrm{cu} \pm$ straight. Whole insect less shiny ..pavoniae (Scopoli)

Median area coriaceous. $2 \mathrm{~m}$-cu \pm bent apically. Whole insect more shining rectanulus Roman 
Acknowledgements: It is my pleasure to thank following persons: Dr. J. Kolarov (University of Sofia), for the loaning of the holotype of $S$. adanaensis, and Dr. D. Kasparyan (Russian Academy of Sciences, St. Petersburg), Dr. M. Schwarz (University of Salzburg), Dr. M. Shaw (National Museums of Scotland, Edinburgh), and Dr. G. van Rossem (Leiden, dead 1990) for the loaning of other Stilpnus material. I am also grateful to Dr. Kasparyan, M.Sc. Gergely Várkonyi (University of Oulu, Finland) and to two anonymous referees for valuable comments on an earlier version of the manuscript.

\section{References}

Gauld, I. D. 1991: The Ichneumonidae of Costa Rica, 1. Introduction, keys to subfamilies, and keys to the species of the lower pimpliform subfamilies Rhyssinae, Pimplinae, Poemeniinae, Acaenitinae and Cylloriinae. - Mem. Amer. Entomol. Inst. 47: 600 p.

Gauld, I. D. \& Bolton, B. 1988: The Hymenoptera. - Brit. Mus. (Nat. Hist.) \& Oxford Univ. Press: 332 p.

Jussila, R. 1987: Revision of the genus Stilpnus (Hymenoptera, Ichneumonidae) of the western Palaearctic Region. - Ann. Entomol. Fenn. 53: 1-16.

Jussila R. 1988: Stilpnus (Hymenoptera: Ichneumonidae) from Japan and Taiwan. - Oriental Insects 22: 99-114.

Kolarov, J. \& Beyarslan, J. 1994: Agrothereutes tiloidalis sp. nov. und Stilpnus adanaensis sp. nov. zwei neue Ichneumoniden - Arten aus der Türkei (Hymenoptera: Ichneumonidae: Cryptinae). — Linzer. biol. Beitr. 26: 179-185. 